\title{
PRODUCTIVITY AND COSTS OF FOREST CUTTING IN A PINE STAND UNDER TWO THINNING METHODS
}

\author{
Oscar Manuel de Jesús Vera Cabral ${ }^{1}$, Eduardo da Silva Lopes ${ }^{2}$, Carla Krulikowski Rodrigues ${ }^{3 *}$, Afonso Figueiredo \\ Filho $^{2}$
${ }^{1}$ Universidad Nacional de Asunción, Carrera Ingeniería Forestal, Asunción, Paraguay - e-mail: oscar.vera@agr.una.py
${ }^{2}$ Universidade Estadual do Centro-Oeste, Programa de Pós-Graduação em Ciências Florestais, Irati, Paraná, Brasil- e-mail: eslopes@ unicentro.br; afigfilho@gmail.com
3* Universidade Federal do Paraná, Departamento de Ciências Florestais, Curitiba, Paraná, Brasil - e-mail: carlakr@ gmail.com

Received for publication: 02/05/2019 - Accepted for publication: 02/07/2020

\begin{abstract}
Resumo
Produtividade e custo do corte florestal em povoamentos de pinus submetidos a dois métodos de desbaste. A necessidade de produtos madeireiros de maior valor agregado e o elevado custo das operações mecanizadas estimulam o desenvolvimento de novos métodos de desbaste, a fim de proporcionarem ganhos na capacidade produtiva dos povoamentos florestais. Neste contexto, objetivou-se analisar o efeito de dois métodos de desbaste na produtividade e nos custos do corte florestal na geração de multiprodutos. O estudo foi realizado em povoamento de Pinus taeda, com 10 anos de idade, submetidos a dois métodos de desbaste: TH5 (harvester, com eliminação sistemática da quinta linha e seletiva nas adjacentes); e TH7 (motosserra e harvester, com eliminação sistemática da sétima linha e seletiva nas adjacentes). Através do estudo de tempos e movimentos, determinou-se os tempos dos ciclos operacionais, a produtividade e os custos de produção, sendo as médias dos tempos parciais e totais comparadas entre métodos de desbaste pelo teste Wilcoxon-Mann-Whitney $(\alpha \leq 0,05)$. Com os resultados obtidos, verificou-se que os métodos de desbaste afetaram diretamente os tempos parciais e totais do harvester, sendo os maiores obtidos no método de desbaste TH7 devido à necessidade de localizar as árvores derrubadas anteriormente com a motosserra, com consequente redução da produtividade e aumento do custo de produção, se comparado ao método TH5. Entretanto, o método TH7, apesar do maior custo de produção mostrou potencialidade com uso da mecanização em todas as atividades, possibilitando ampliar o desbaste seletivo e contribuir com ganhos em qualidade do povoamento florestal.

Palavras-chave: alcance efetivo da grua; colheita da madeira; mecanização.
\end{abstract}

\begin{abstract}
The need for higher value-added wood products and the high cost of mechanized operations stimulate the development of new thinning methods in order to provide gains in productive capacity of forest stands. In this context, the aim of this study was to analyze the effect of two thinning methods on productivity and costs of the forest harvesting in the generation of multi-products. The study was carried out in a 10-year-old Pinus taeda stand under to two thinning methods: TH5 (harvester, with systematic harvesting of the fifth tree row and selective in adjacent rows); and TH7 (chainsaw and harvester, with systematic harvesting of the seventh tree row and selective in adjacent rows). We determined the working cycle times, productivity, and production costs through a time and motion study, with the averages of partial and total times being compared between thinning methods by the Wilcoxon-Mann-Whitney test $(\alpha \leq 0.05)$. From the obtained results, it was found that the thinning methods directly affected the harvester's partial and total times, with the largest time obtained in the TH7 thinning method due to the need to locate previously cut trees by chainsaw, with a consequent reduction in the productivity and an increase in the production costs when compared to the TH5 method. However, despite the higher production cost, the TH7 method showed potential with the use of mechanization in all activities, making it possible to increase selective thinning and contribute to gains in forest stand quality.

Keywords: effective reach of crane; wood harvesting; mechanization.
\end{abstract}

\section{INTRODUCTION}

Thinning is an important silvicultural treatment in managing forest stands for commercially producing wood for multi-products. It is the intentional, planned, rational and judicious removal of part of the trees from the stand, seeking to manage or regulate competition among the remaining trees and add value through quality, with an expansion in possibilities for different uses and wood applications (CAMPOS; LEITE, 2017).

With the development and growth trend in the planted forest sector, new demands for products are generated in the search for greater competitiveness in the economic market, implying important changes in work methods and

FLORESTA, Curitiba, PR, v. 50, n. 4, p. 1883 - 1891, out/dez 2020.

Cabral, O. M. J. V. et.al.

ISSN eletrônico 1982-4688

DOI: $10.5380 /$ rf.v50 i4. 66647 
procedures (SPINELLI; MAGAGNOTTI, 2011). In this sense, the mechanization of thinning operations constitutes an important innovation front, enabling numerous advantages in the forest production chain (SPINELLI et al., 2014).

Generating new knowledge on the use of mechanization in thinning is mainly oriented to its performance means, being represented by the high technology of the current forestry machines (JUNDÉN et al., 2013). In this aspect, the need for knowledge of the method of harvesting trees from the stand during thinning is highlighted, in which the systematically harvested tree rows are defined by the characteristics of the machines which often disregard the forest attributes and the best forest management strategies.

Mechanized thinning in pine stands in Brazil is a traditional practice with the cut-to-length system normally being employed and harvest of the fifth tree row in a systematic way. This is defined by the reach of the hydraulic arm of the machine and selective harvest in the adjacent rows, as described by several authors such as Rodrigues et al. (2017) and Lopes et al. (2018). Thinning under this method can usually cause operational problems due to the excessive amount of tree rows harvested under a very short interval.

Thus, the use of methods which seek to maximize the intervals of removing whole rows of trees are suggested to perform thinning, thereby enabling the machine to enter into the stand so that they cause less traffic, environmental impacts on the soil and damage to the remaining trees of the stand (MARCHI et al., 2014; CAMBI et al., 2018; MEDERSKI et al., 2018). Then, Mederski (2006) proposed adopting the combination of chainsaw and harvester in order to increase the spacing between the machine strip roads and to reduce the number of strip roads because with the chainsaw it is possible to perform preliminary felling of the trees located out of the cutting machine's reach (midfield), directing them to the harvester's strip road.

Therefore, this study had the hypothesis that forest cutting could be more productive and less costly if systematic thinning on the seventh tree row and selective thinning in the adjacent rows was employed through the chainsaw consortium with the harvester, as this would enable the harvester to have more trees available within reach at the same point on the traffic trail. Considering the above, this study aimed to analyze forest harvesting under two thinning methods in a Pinus taeda stand by measuring: (1) the average times of the partial activities of the chainsaw and harvester working cycles; (2) productivity; and (3) production costs in order to obtain information that contributes to planning forest operations and decision-making by forest managers.

\section{MATERIAL AND METHODS}

The study was conducted at a forestry company located in the Western region of the Paraná State, Brazil, at the geographic coordinates of $25^{\circ} 26^{\prime} 27^{\prime \prime} \mathrm{S}$ and $52^{\circ} 55^{\prime} 17^{\prime \prime} \mathrm{W}$. The climate is $\mathrm{Cfb}$ according to the Köppen classification, with average temperatures of $22^{\circ} \mathrm{C}$ in summer and $18^{\circ} \mathrm{C}$ in winter (ALVARES et al., 2013). The predominant soil type is Lithic Leptsols, with flat to wavy topography, an average slope of $7.6 \%$ and altitude of $600 \mathrm{~m}$.

The experiment was established on 16.3 hectares of Pinus taeda L. stand under first commercial thinning, with approximately 8.15 hectares to apply two thinning methods located side by side, with homogeneous characteristics regarding soil type, relief and site, as identified by Geographic Information System and forest inventory tools. The studied stand was 10 years old with $3 \mathrm{~m} \times 2 \mathrm{~m}$ spacing and the following variables: diameter at breast height of 20.5 $\mathrm{cm}$; average total height of $17.4 \mathrm{~m}$; basal area of $33.7 \mathrm{~m}^{2} \mathrm{ha}^{-1}$; and average individual stem volume over the bark of 0.3 $\mathrm{m}^{3}$. These stand characteristics enabled producing different assortments for industrial processes (saw log and veneer $\log$ ) and energy (Table 1).

Table 1. Assortments obtained in thinning of a $P$. taeda stand.

Tabela 1. Sortimentos obtidos no desbaste de um povoamento de P. taeda.

\begin{tabular}{ccccc}
\hline \multirow{2}{*}{ Assortments } & Destination & Length $(\mathbf{m})$ & $\begin{array}{c}\text { Minimum diameter } \\
\text { over bark (cm) }\end{array}$ & $\begin{array}{c}\text { Maximum diameter } \\
\text { over bark (cm) }\end{array}$ \\
\cline { 3 - 5 } Industrial wood & Saw log & 2.7 & 20.5 & 35.5 \\
& Veneer log & 3.6 & 20.5 & 35.5 \\
\hline Energy wood & Fuel wood & 3.1 & 3.5 & 20.4 \\
\hline
\end{tabular}

We used a harvester with a $115 \mathrm{hp}$ engine equipped with crawler wheels, a $9.2 \mathrm{~m}$ reach crane and a $0.63 \mathrm{~m}$ processor head, which is responsible for cutting and processing the wood. In addition, a chainsaw with a $5.3 \mathrm{hp}$ engine, $6.6 \mathrm{~kg}$ of weight without fuel and a sabre in the length of $0.40 \mathrm{~m}$ was used.

Thinning was conducted by the mixed method, with systematic harvesting of the tree row and selective harvesting of the adjacent tree rows of the forest stand. The following thinning methods were evaluated: TH5

FLORESTA, Curitiba, PR, v. 50, n. 4, p. 1883 - 1891, out/dez 2020.

Cabral, O. M. J. V. et.al.

ISSN eletrônico 1982-4688

DOI: $10.5380 /$ rf.v50 i4. 66647 
(harvester, with systematic harvesting of the fifth tree row and selective in adjacent rows); and TH7 (chainsaw and harvester, with systematic harvesting of the seventh tree row and selective in adjacent rows). Both thinning methods removed $50 \%$ of the initial individuals, plus the mortality rate. For a better understanding of thinning methods, Figure 1 illustrates the theoretical methods of tree availability for the harvester according to machine movement in each thinning treatment studied. It is noted that trees out of the machine's reach were cut down with the chainsaw before the harvester operation in the TH7 method.

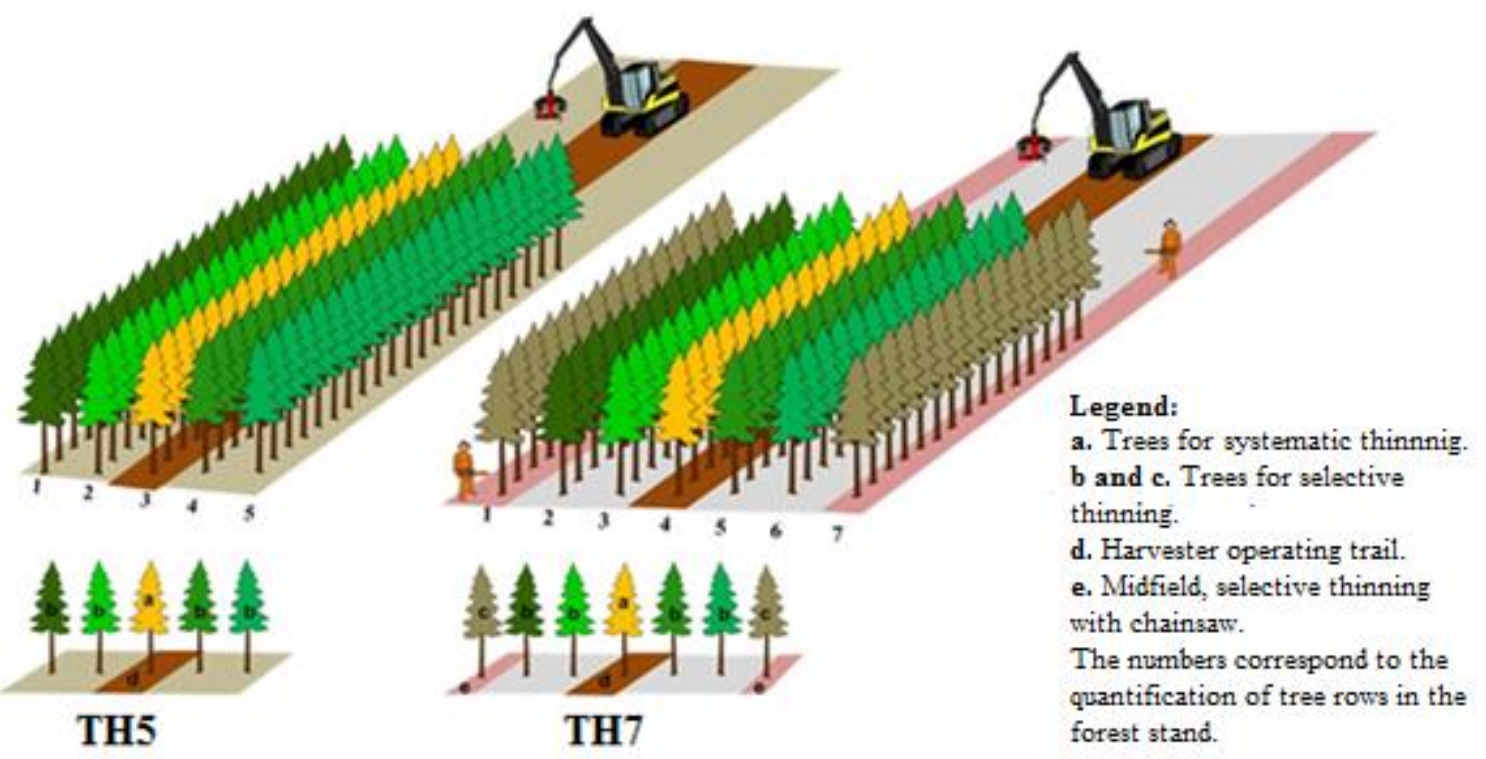

Figure 1. Availability of trees according to harvester machine movement.

Figura 1. Disponibilidade de árvores para o harvester de acordo com o deslocamento da máquina.

A time and motion study was carried out using the "continuous timing" method to determine the total working cycle times, as well as the times of the partial activities, which was characterized by obtaining the times without the stop of the centesimal stopwatch used. A pilot study was carried out to define the sampling procedure in order to define the number of working cycles required to reach the 5\% sampling error limit, using the expression (1) proposed by Murphy (2005).

$$
\mathrm{n}=\frac{\mathrm{t}^{2} \times \operatorname{Var}(\mathrm{WCT})}{\left(\mathrm{E} \times \frac{\overline{\mathrm{WCT}}}{100}\right)^{2}}
$$

In which: $\mathrm{n}=$ number of working cycles to be studied; $\mathrm{t}=$ Student's $\mathrm{t}$-value; Var (WCT) variance of the work cycle time; $\mathrm{E}=$ level of precision required $(5 \%)$; and $\overline{\mathrm{WCT}}=$ mean work cycle time (seconds).

The harvester working cycles were divided into partial activities: searching and cutting (time understood as the crane and processor head movement in searching for a tree to be cut until separation of the tree from the stump, as well as searching and harvesting the trees previously felled by the chainsaw and cutting a disc at the base to drive the processor head in the TH7 treatment); processing (time from separating the tree from the stump to completing delimbing, bucking, and stacking the logs in the different assortments, when necessary); and movement (time of machine movement between the trees into the stand).

The chainsaw operational cycles were divided into the following partial activities: displacement (time consumed with displacement of the operator between trees previously selected to be cut); felling (time understood to execute the felling of the tree at its base and fall); and overturning (time understood between the fall and the assistance of the chainsaw operator in forcing the fall of the tree stuck in the branches of the remaining trees, since it was not possible to execute the free fall to the ground. In addition, it should be noted that the delays for both the harvester and

FLORESTA, Curitiba, PR, v. 50, n. 4, p. 1883 - 1891, out/dez 2020. 
the chainsaw were classified according to the nomenclature suggested by the International Union of Forest Research Organizations - IUFRO.

The utilization rate (ACKERMAN et al., 2014) was calculated as the ratio of delay-free productive machine hours $\left(\mathrm{pmh}_{0}\right)$ to programmed machine hours with delays $(\mathrm{smh})$, and was represented by the part of the working time in which the machine was performing its intended functions (PULKKI, 2001). This analysis was carried out as a premise for hourly operating cost analyses (Table 3$)$. Productivity per machine hour $\left(\mathrm{m}^{3} \mathrm{pmh}_{0}^{-1}\right)$ was determined as proposed by Magagnotti et al. (2017).

The hourly operating costs $(\mathrm{COH})$ were obtained by the accounting method using estimated and actual values being defined by the sum of fixed, variable, personnel and management costs. The expressions used are presented in Table 2, while the actual and literature data used are presented in Table 3.

Table 2. Expressions used for calculations of hourly operating costs (COH).

Tabela 2. Expressões utilizadas para os cálculos dos custos operacionais horários $(\mathrm{COH})$.

\begin{tabular}{|c|c|}
\hline Fixed Costs (FC) & $\mathrm{Dp}+\mathrm{II}$ \\
\hline a) Depreciation $(\mathrm{Dp})$ & $(\mathrm{Av}-\mathrm{Rv}) /(\mathrm{L} \times \mathrm{EHY})$ \\
\hline b) Interest and Insurance (II) & $(\mathrm{AAI} \times \mathrm{i}) / \mathrm{EHY}$ \\
\hline * Annual average investment (AAI) & $(((\mathrm{Av}-\mathrm{Rv}) \times(\mathrm{L}+1)) /(2 \times \mathrm{L}))+\mathrm{Rv}$ \\
\hline * Interest and Insurance rate (i) & IntR + InsR \\
\hline Variable Costs (VC) & $\mathrm{Fu}+\mathrm{Lu}+\mathrm{HO}$ \\
\hline a) Fuel $(\mathrm{Fu})$ or $\mathrm{Fu}+$ two stroke oil & $\mathrm{FC} \times \mathrm{FP}$ \\
\hline b) Lubricants and greases ( $\mathrm{Lu}$ ) or chain oil & $\mathrm{LGI} \times \mathrm{FC}$ \\
\hline c) Hydraulic oil (HOI) (only harvester) & $\mathrm{HOI} \times \mathrm{FC}$ \\
\hline Personnel Cost (PC) & $\mathrm{Ma}+\mathrm{TP}+\mathrm{TM}+\mathrm{PR}$ \\
\hline a) Maintenance (Ma) & \\
\hline a.1) Harvester & $(\mathrm{MAV} /(\mathrm{L} \times \mathrm{EHY})) \times 0,5+(\mathrm{IAV} /(\mathrm{L} \times \mathrm{EHY})) \times 0,25$ \\
\hline a.2) Chainsaw & $\mathrm{MI} \times \mathrm{Dp}$ \\
\hline b) Transport of personnel (TP) & $(\mathrm{Akm} / \mathrm{EHY}) \times \mathrm{PAkm}$ \\
\hline c) Transport of machinery (TM) & MTI $\times$ DC \\
\hline d) Personnel remuneration (PR) & $((\mathrm{Sa} \times \mathrm{NO} \times 12) / \mathrm{EHY}) \times \mathrm{SSC} / 100+((\mathrm{Sa} \times \mathrm{NO} \times 12) / \mathrm{EHY})$ \\
\hline Administrative Costs (AC) & $\mathrm{DC} \times \mathrm{k}$ \\
\hline$*$ Direct cost $(\mathrm{DC})$ & $\mathrm{FC}+\mathrm{VC}$ \\
\hline OPERATIONAL COST (OC) & $\mathrm{FC}+\mathrm{VC}+\mathrm{PC}+\mathrm{DC}$ \\
\hline
\end{tabular}

Legend: $A v=$ acquisition value (machine + implement); Rv = resale value (machine + implement); L = Lifetime; EHY = effective hours in the year; IntR = interest rate; InsR = insurance rate; FC = fuel consumption; $\mathrm{FP}=$ fuel price; $\mathrm{MAV}=$ machine's acquisition value; $\mathrm{IAV}=$ implement's acquisition value; $\mathrm{Akm}=$ average annual $\mathrm{km}$ of personnel transport; $\mathrm{PAkm}=$ price of average annual $\mathrm{km}$ of personnel transport; MTI = Machine transport index; $\mathrm{Sa}=$ average salary in the region for operator, chainsawman and helper; $\mathrm{NO}=$ number of operators, chainsawman and helper; $\mathrm{SSC}=$ rate of social security charges; and, $\mathrm{k}=$ administrative cost rate.

The production cost was calculated by equation (2). In addition, it should be noted that the cost of the trees felled with the chainsaw was added to the cost of harvesting with the harvester in the TH7 method.

$$
\mathrm{PC}=\frac{\mathrm{OC}}{\mathrm{P}_{\mathrm{pmh} 0}}
$$

where: $\mathrm{PC}=$ production cost $\left(\mathrm{U} \$ \mathrm{~m}^{-3}\right) ; \mathrm{OC}=$ operating cost $\left(\mathrm{U} \$ \mathrm{pmh}_{0}{ }^{-1}\right) ;$ and $\mathrm{Ppmh}_{0}=$ productivity per productive machine hour $\left(\mathrm{m}^{3} \mathrm{pmh}_{0}^{-1}\right)$.

Table 3. Data used for calculating hourly operating costs.

FLORESTA, Curitiba, PR, v. 50, n. 4, p. 1883 - 1891, out/dez 2020. 
Tabela 3. Dados utilizados para os cálculos de custos operacionais horários.

\begin{tabular}{|c|c|c|c|}
\hline \multicolumn{2}{|r|}{ Data } & \multirow{2}{*}{$\frac{\text { Harvester }}{4}$} & \multirow{2}{*}{$\begin{array}{c}\text { Chainsaw } \\
2\end{array}$} \\
\hline \multirow{9}{*}{ Operacional } & Lifetime (years) & & \\
\hline & Cutting element lifetime (hours) & - & 1.507 \\
\hline & Scheduled hours for shift work (hours) & 8 & 8 \\
\hline & Number of shifts per day & 2 & 1 \\
\hline & Days worked per month (hours) & 24 & 24 \\
\hline & Days worked per year (hours) & 288 & 288 \\
\hline & Hours of use per year (hours) & 4,608 & 2,304 \\
\hline & Average machine utilization rate for TH5 and TH7 treatments (\%) & 68.2 & 65.4 \\
\hline & Scheduled hours not year (hours) & 3,143 & 1,507 \\
\hline \multirow{19}{*}{ Economic } & Machine's acquisition value (MAV) (R\$) & $550,000.00$ & $2,150.00$ \\
\hline & Implement's acquisition value (IAV) (R\$) & $260,000.00$ & - \\
\hline & Acquisition value of the saber and chain $(\mathrm{R} \$)$ & - & 127.3 \\
\hline & Depreciation rate $(\%)$ & 20 & 20 \\
\hline & Residual value machine and processor head $(\mathrm{R} \$)$ & $162,000.00$ & 455.46 \\
\hline & Interest rate per year (IntR) $(\%)$ & 8 & 8 \\
\hline & Insurance rate (InsR) (\%) & 4 & 4 \\
\hline & Diesel fuel consumption per hour (FC) $\left(\mathrm{L} \mathrm{h}^{-1}\right)$ & 17 & - \\
\hline & Average market price of diesel fuel per liter (FP) $(\mathrm{R} \$)$ & 2.10 & - \\
\hline & Consumption of the mixture (Fuel + two stroke oil) per hour $(\mathrm{R} \$)$ & - & 1.16 \\
\hline & Price of the mixture (Fuel + two stroke oil $)(\mathrm{R} \$)$ & - & $3 ; 65$ \\
\hline & Chain oil consumption per hour $(\mathrm{R} \$)$ & - & 0.9 \\
\hline & Chain oil price $(\mathrm{R} \$)$ & - & 1.30 \\
\hline & Lubricant and grease cost index (LGI) $(\%)$ & 20 & - \\
\hline & Hydraulic oil cost index (HOI) $(\%)$ & 50 & - \\
\hline & Maintenance cost index (MI) $(\%)$ & 80 & 80 \\
\hline & Average annual $\mathrm{km}$ of personnel transport $(\mathrm{Akm})(\mathrm{km})$ & 3,200 & 3,200 \\
\hline & Price of average annual $\mathrm{km}$ of personnel transport (PAkm) $(\mathrm{R} \$ / \mathrm{km})$ & 1.00 & 1.00 \\
\hline & Machine transport index, obtained in literature (MTI) $(\%)$ & 10 & - \\
\hline \multirow{3}{*}{ Social } & Average salary in the region for operator, chainsaw operator and assistant (Sa) & $2,328.00$ & $1,380.00$ \\
\hline & Number of operators, chainsaw operator and assistant (NO) & 2 & 2 \\
\hline & Rate of social security charges, obtained in literature (SSC) & 70 & 70 \\
\hline \multicolumn{2}{|c|}{ Administrative cost rate $(\mathrm{k})$, obtained in literature $(\%)$} & 10 & 10 \\
\hline \multicolumn{2}{|c|}{ Conversion factor from reais (R\$) to US dollars (U\$) } & \multicolumn{2}{|c|}{3.82} \\
\hline
\end{tabular}

Observations of the partial and total times of the harvester's work cycles (repetitions) were evaluated by the non-parametric Wilcoxon-Mann-Whitney test $(\alpha \leq 0.05)$ for both thinning methods (treatments), since the treatments are independent and the observations did not show normal distribution.

\section{RESULTS}

We timed 4,897 and 3,931 harvester working cycles which corresponds to the minimum number of observations required of 291 and 342 in TH5 and TH7 thinning methods, respectively. In the chainsaw cutting operation we timed 1,066 working cycles, requiring only 355 cycles to reach the $5 \%$ error limit.

The total average time of the operating cycles of the chainsaw cut was 25.4 seconds, with emphasis on the presence of the partial activity "overturning", which corresponds to the attempt to cut the tree to the ground, since the felled trees were trapped in the remaining ones in $92 \%$ of the cycles (Table 4). Such characteristics of the chainsaw cutting were directly influential on the results obtained from the partial and total times of the harvester in the TH7 treatment.

Table 4. Average times of partial activities and total activities of the chainsaw and harvester operating cycles in TH5 and TH7 thinning methods.

FLORESTA, Curitiba, PR, v. 50, n. 4, p. 1883 - 1891, out/dez 2020. 
Tabela 4. Tempos médios das atividades parciais e totais dos ciclos operacionais da motosserra e do harvester nos métodos de desbaste TH5 e TH7.

\begin{tabular}{|c|c|c|c|c|}
\hline Machine & \multicolumn{4}{|c|}{ Chainsaw } \\
\hline \multirow{2}{*}{ Activities } & \multicolumn{2}{|c|}{ Treatments } & \multirow{2}{*}{$\mathrm{U}$} & \multirow{2}{*}{ Significance } \\
\hline & TH5 & TH7 & & \\
\hline Displacement (s) & - & 11.0 & - & - \\
\hline Felling (s) & - & 11.1 & - & - \\
\hline Overturning (s) & - & 3.4 & - & - \\
\hline Total (s) & - & 25.4 & - & - \\
\hline Machine & \multicolumn{4}{|c|}{ Harvester } \\
\hline \multirow{2}{*}{ Activities } & \multicolumn{2}{|c|}{ Treatments } & J & Sionificance \\
\hline & TH5 & TH7 & 0 & Signimidatice \\
\hline Searching and cutting (s) & 5.0 & 7.6 & $6,507,566.0$ & $*$ \\
\hline Processing $(\mathrm{s})$ & 17.3 & 16.3 & $2,067,904.0$ & * \\
\hline Movement (s) & 2.4 & 2.8 & $8,719,753.5$ & * \\
\hline Total (s) & 24.7 & 26.7 & $9,135,068.0$ & * \\
\hline
\end{tabular}

Legend: $\mathrm{s}=$ seconds; $\mathrm{U}=$ calculation of statistics; and * significant by Wilcoxon-Mann-Whitney test $(\alpha \leq 0.05)$.

In order to be able to compare the effects of thinning methods, the trees cut down by the chainsaw were considered in the same partial "searching and cutting" activity as the trees cut down by the harvester. Thus, it was observed that the time consumed in the harvester's partial activity "searching and cutting" in the TH7 thinning method was directly influenced by the need to perform the search for previously felled trees with the chainsaw, as well as by the requirement of greater attention from the machine operator in order to not damage the remaining trees.

When analyzing the partial activity "processing" of the harvester, the average times were lower in the TH7 method since there was greater removal of small trees for the production of logs destined only for energy, which are less time consuming since they do not have the need to separate assortments when generating multi-products (saw log, veneer $\log$ and fuel wood).

Regarding the average displacement times, the TH7 method showed higher values when compared to the TH5 method, which contradicted the hypothesis that the TH7 treatment would consume less time with movement due to the greater wood availability at the same stationary point of the machine. This was caused by the fact that the trees harvested by the chainsaw were in most cases trapped between the treetops of the remaining trees, and consequently affected the visibility of the harvester operator.

Thus, the harvester in the TH5 thinning method consumed an average of 24.7 seconds to run the operating cycles, being significantly lower than the TH7 method with an average of 26.7 seconds. Thus, the productivity per machine hour as well as the machine production cost were directly influenced by the average working cycle times (Table 5).

Table 5. Utilization rate, productivity, production and costs of forest cutting in TH5 and TH7 thinning methods.

Tabela 5. Taxa de utilização, produtividade, produção e custos do corte florestal nos métodos de desbaste TH5 e TH7.

\begin{tabular}{|c|c|c|c|c|c|}
\hline Treatment & Machines & $\begin{array}{c}\text { Utilization } \\
\text { rate } \\
(\%)\end{array}$ & $\begin{array}{c}\text { Productivity } \\
\left(\mathbf{m}^{3} \mathbf{p m h}_{0}^{-1}\right)\end{array}$ & $\begin{array}{c}\text { Production cost of } \\
\text { machine } \\
\left(\mathbf{U} \$ \mathbf{~ m}^{-3}\right)\end{array}$ & $\begin{array}{c}\text { Production cost of } \\
\text { forest cutting } \\
\left(\mathbf{U} \$ \mathbf{~ m}^{-3}\right)\end{array}$ \\
\hline TH5 & Harvester & 65.9 & 42.0 & 1.34 & 1.34 \\
\hline TH7 & $\begin{array}{l}\text { Chainsaw } \\
\text { Harvester }\end{array}$ & $\begin{array}{l}65.4 \\
71.0\end{array}$ & $\begin{array}{l}41.0 \\
39.0\end{array}$ & $\begin{array}{l}1.47 \\
0.30\end{array}$ & 1.76 \\
\hline
\end{tabular}

The harvester's productivity showed a reduction of $3 \mathrm{~m}^{3} \mathrm{pmh}_{0}^{-1}$ between TH5 and TH7 methods, which can not only be justified by the longer total time of the operational cycle, but also by the number of trees of lower individual volume selectively removed in the TH7 method due to the removal of fewer rows in the systematic thinning of the stand. In addition, the productivity effect was directly reflected in production costs which varied from U\$ 1.34 to 1.76 per 1 cubic meter of wood over bark, with higher value in the TH7 method.

In addition, low values were observed in both thinning methods for the harvester utilization rate due to the operator's need to organize the log pile during processing, followed by the high presence of native vegetation within the forest stand which affected the operator's visibility. The utilization rate for the chainsaw was affected by the

FLORESTA, Curitiba, PR, v. 50, n. 4, p. 1883 - 1891, out/dez 2020. 
presence of trees trapped in the remains during cutting, where the chainsaw operator tried to arrange the cut trees on the ground.

\section{DISCUSSION}

When comparing the two thinning methods, it was noted that the partial activity "searching and cutting" was greater in the TH7 method, because the harvester still needed to perform a search for previously cut trees with the chainsaw in addition to cutting trees located in the rows of trees within reach of the crane. In this situation, the spacing and the size of the branches made it difficult to cut down the trees cut down by the chainsaw, and consequently the search for these trees by the harvester. For Bonazza (2019), selective thinning from below carried out with a chainsaw may cause the presence of trees trapped in the remaining trees due to the intensity of thinning with a higher incidence in areas with less space for tree cutting.

Regarding the time consumed in the partial "processing" activity, it was observed that there was a difference between the thinning methods applied, with longer times being observed in TH5 treatment compared to TH7. This variation in time occurred due to the need to separate the logs into stacks for sawn logs, veneer logs and fuel wood caused by the presence of a greater quantity of larger trees. Such results were also described by Lopes et al. (2017) when assessing the harvester in the thinning operation of Pinus spp. under different topographic conditions, finding that the wood processing is affected by the need to produce different assortments.

As for the longer movement time in the TH7 method, it is worth noting that the operator had to move the machine to aid visibility before starting the partial "search and cut" activity. Thus, the operator found the most suitable position for the machine so that no damage was caused to the remaining trees. Several studies such as Picchio et al. (2011) and Lopes et al. (2018) report the existence of damage to trees after a thinning operation and the need for such care so that they do not affect the health and production of the remaining forest stand.

Thus, it became evident that the "total" working cycle time was directly affected by the partial times as described above, and the time consumed in the TH7 method was greater than TH5. This directly affected productivity and production cost values. On the other hand, although the TH7 method presents a higher production cost, this method makes it possible to increase selective thinning, and may provide gains in the productive capacity of forest stands.

The results obtained are in agreement with Mederski et al. (2018), who stated that the harvester presented lower productivity and higher production cost when working together with the chainsaw due to the operational difficulty for the chainsaw operator to control the midfield location between the two harvester's strip roads, as well as to carry out the overturning in the direction of the strip road. However, the authors proposed another method of thinning in which the first harvesting pass was carried out, followed by chainsaw felling, and another harvesting pass. The process became easier in this method since the midfield area was visible and it was easier to cut down the trees where harvesting with a harvester had been carried out, but the two harvester passes significantly increased the costs.

On the other hand, it should be noted that the results obtained herein were in contrast with the Mederski study (2006) which was used to formulate the hypothesis of this study, since the author reported higher harvester productivity in the thinning method with the midfield. This is due to the fact that the study by Mederski (2006) was performed in old forest stands undergoing the third and fourth thinning, and the cutting operation with chainsaws was facilitated.

Within this context, although the TH7 method presented a reduction in productivity and an increase in production cost, the values were within acceptable, and thus showed potential for expanding selective thinning and contributing to gains in forest stand quality. In addition, despite the operational difficulties encountered in this study regarding the yield of harvesting operations with the harvester in $\mathrm{TH} 7$ thinning method, there are other possible aspects to be considered when deciding how to conduct the operation, such as: growth and production of stands, damage to remaining trees, and lower levels of soil disturbance, among others (PICCHIO et al., 2012; NAKAHATA et al., 2014; LOPES et al., 2018).

\section{CONCLUSIONS}

- The TH7 thinning method using the chainsaw and harvester, and systematic thinning of the seventh row of trees in the stand and selective thinning in the adjacent rows, showed reduced harvester productivity and increased production costs when compared to the TH5 thinning method;

- The operation in the TH7 method consumed more time in locating the trees previously felled by the chainsaw and obtained the lowest individual volume harvested by selective thinning; and

- Although the TH7 method had a higher production cost, it enabled expanding selective thinning.

FLORESTA, Curitiba, PR, v. 50, n. 4, p. 1883 - 1891, out/dez 2020.

Cabral, O. M. J. V.et.al.

ISSN eletrônico 1982-4688 


\section{ACKNOWLEDGEMENTS}

The present study was carried out with the support of the Coordenação de Aperfeiçoamento de Pessoal de Nível Superior - Brasil (CAPES) - Código de Financiamento 001.

\section{REFERENCES}

ACKERMAN, P.; GLEASURE, E.; ACKERMAN, S.; SHUTTLEWORTH, B. Standards for time studies for the South African forest industry. South African: ICFR/FESA, 2014. 49 p.

ALVARES, C. A.; STAPE, J. L.; SENTElHAS, P. C.; GONÇALVES, J. L. M.; SPAROVEK, G. Köppen's climate classification map for Brazil. Meteorologische Zeitschrift, v. 22, n. 6, p. 711-728, 2013.

BJÖRHEDEN, R.; APEL, K.; SHIBA, M.; THOMPSON, M. A. IUFRO Forest work study nomenclature. Garpenberg: Departament of Operational Efficiency, Swedish University of Agricultural Science, 1995. 16 p.

BONAZZA, M. Alternativas operacionais no desbaste e corte final em florestas de Pinus taeda. $147 \mathrm{f}$. Tese (Programa de Pós-Graduação em Engenharia Florestal). Universidade Federal do Paraná, Curitiba, 2019.

BURLA, E. S.; FERNANDES, H. C.; MACHADO, C. C.; LEITE, D. M.; FERNANDES, P. S. Avaliação técnica e econômica do harvester em diferentes condições operacionais. Engenharia na Agricultura, Viçosa, v. 20, n. 5, p.412$422,2012$.

CAMBI, M.; GIANNETTI, F.; BOTTALICO, F.; TRAVAGLINI, D.; NORDFJELL, T.; CHIRICI, G.; MARCHI, E. Estimating machine impact on strip roads via close-range photogrammetry and soil, parameters: A case study in central Italy. iForest, v. 11, p. 148-154, 2018.

CAMPOS, J. C. C.; LEITE, H. G. Mensuração Florestal: Perguntas e Respostas. 5 ed. Viçosa: UFV, 2017. 636 p.

JUNDÉN, L.; BERGSTRÖM, D.; SERVIN, M.; URBANO, B. Simulation of boom-corridor thinning using a doublecrane system and different levels of automation. International Journal of Forest Engineering, v. 24, n. 1, p. 16-23, 2013.

LOPES, E. S.; OLIVEIRA, F. M.; DROOG, A. Damage to residual trees following commercial thinning by harvester and forwarder in a Pinus taeda stand in Southern Brazil. Scientia Forestalis, v. 46, n. 118, p. 167-175, 2018.

LOPES, E. S.; ROZA, B. L.; OLIVEIRA, F. M. Efeito de variáveis operacionais na produtividade de um harvester de pneus no desbaste de pinus. Floresta, v. 47, n. 4, p.417- 426, 2017.

MAGAGNOTTI, N.; PARI, L.; SPINELLI, R. Use, Utilization, Productivity and Fuel Consumption of Purpose-Built and Excavator-Based Harvesters and Processors in Italy. Forests, v. 8, n. 485, p. 1-12, 2017.

MARCHI, E.; PICCHIO, R.; SPINELLI, R.; VERANI, S.; VENANZI, R.; CERTINI, G. Environmental impact assessment of different logging methods in pine forests thinning. Ecological Engineering, v. 70, p. 429-436, 2014.

MEDERSKI, P. Comparison of harvesting productivity and costs in thinning operations with and without midfield. Forest Ecology and Management, v. 224, n. 1, p. 286-296. 2006.

MEDERSKI, P. S.; VENANZI, R.; BEMBENEK, M.; KARASZEWSKI, Z.; ROSIŃSKA, M.; PILAREK, Z.; LUCHENTI, I.; SURUS, M. Designing Thinning Operations in 2nd Age Class Pine Stands - Economic and Environmental Implications. Forests, v. 9, n. 335, p. 1-12, 2018.

MURPHY, G. Determining sample size for harvesting cost estimation. New Zealand Journal of Forestry Science, v. 35 , n. $2 / 3$, p. $166-169,2005$.

NAKAHATA, C.; ARUGA, K.; SAITO, M. Examining the optimal bucking method to maximize profits in commercial thinning operations in Nasunogahara area, Tochigi Prefecture, Japan. Croatian Journal Forest Engineering, v. 35, n. 1, p. 45-65. 2014.

PICCHIO, R.; NERI, F.; MAESANO, M.; SAVELLI, S.; SIRNA, A.; BLASI, S.; BALDINI, S.; MARCHI, E. Growth effects of thinning damage in a Corsican pine (Pinus laricio Poiret) stand in central Italy. Forest Ecology and Management, v. 262, p. 237-243, 2011.

FLORESTA, Curitiba, PR, v. 50, n. 4, p. 1883 - 1891, out/dez 2020. 
PICCHIO, R.; NERI, F.; PETRINI, E.; VENARI, S.; MARCHI, E.; CERTINI, G. Machinery-induced soil compaction in thinning two pine stands in central Italy. Forest Ecology and Management, v.285, p. 38-43, 2012.

PULKKI ,R. E. Forest Harvesting I: On the Procurement of Wood with Emphasis on Boreal and Great Lakes St. Lawrence Forest Regions. 2001. 156 pp.

RODRIGUES, C. K.; LOPES, E. S.; FIGUEIREDO FILHO, A.; SILVA, D. A. Modelagem da biomassa residual da colheita de madeira em povoamentos submetidos ao desbaste com harvester. Biofix Scientific Journal, v. 2, n. Especial I MECFOR, p. 1 - 5, 2017.

SILVA, E. N.; MACHADO, C. C.; FIEDLER, N. C.; FERNANDES, H. C.; PAUlA, M. O.; CARMO, F. C.; MOREIRA, G. R.; COELHO, F. G. Avaliação de custos de dois modelos de harvester no corte de eucalipto. Ciência Florestal, Santa Maria, v. 24, n. 3, p.741-748, 2014.

SILVA, E. N.; MACHADO, C. C.; MINETTE, L. J.; SOUZA, A. P.; FERNANDES, H. C.; SILVA, M. L.; JACOVINI, L. A. Avaliação técnica e econômica do corte mecanizado de Pinus sp. com harvester. Árvore, v. 34, n. 4, p. 745-753, 2010.

SIMÕES, D.; FENNER, P. T.; ESPERANCINI, M. S. T. Avaliação técnica e econômica da colheita de florestas de eucalipto com harvester. Scientia Forestalis, v. 38, n. 88, p. 611-618, 2010.

SPINELLI, R.; LOMBARDINI, C.; MAGAGNOTTI, N. The effect of mechanization level and harvesting system on the thinning cost of Mediterranean softwood plantations. Silva Fennica, v. 48, n. 1, p. 1-15, 2014.

SPINELLI, R.; MAGAGNOTTI, N. The effects of introducing modern technology on the financial, labour and energy performance of forest operations in the Italian Alps. Forest Policy and Economics, v. 13, n. 7, p. 520-524, 2011.

FLORESTA, Curitiba, PR, v. 50, n. 4, p. 1883 - 1891, out/dez 2020. 